\title{
Mała konstrukcja stalowego wiaduktu kolejowego i duży problem naprawczy
}

\author{
A small steel structure of a railway viaduct \\ and great repair problem
}

\section{Streszczenie}

W artykule przedstawiono zagadnienia materiałowe i technologiczne związane z naprawą stalowego przęsła blachownicowego wiaduktu kolejowego, w którym wystąpiły znaczne uszkodzenia korozyjne. Prace naprawcze wymagały restytucji uszkodzonych korozyjnie obszarów przęsła poprzez dospawanie elementów wzmacniających. Opisano zrealizowany zakres prac naprawczych i technologię ich wykonania oraz podano wyniki badań materiałowych elementów wzmacnianych.

Słowa kluczowe: wiadukt stalowy; stal zlewna; spawalność; naprawa

\section{Abstract}

The material and technological issues associated with refurbishment of a steel plate girder span of a railway viaduct with severe corrosion damages are presented. The refurbishment works required to restore areas eroded by corrosion by welding reinforcing materials. The range of the executed refurbishment works and their technology as well as material test results of the strengthened members are presented.

Keywords: steel viaduct; cast steel; weldability; refurbishment

\section{Wstęp}

Mosty kolejowe należą do obiektów o długim okresie eksploatacji. W Polsce prawie połowa mostów kolejowych ma już ponad 100 lat. Spotyka się również drogowe obiekty mostowe o tak długim okresie eksploatacji [1]. Decydujący wpływ na trwałość tych obiektów mają procesy degradacji, które są procesem naturalnym, związanym z eksploatacją i starzeniem się każdej konstrukcji technicznej. Z reguły skutkiem tych procesów są uszkodzenia obiektu mostowego obniżające jego przydatność użytko-

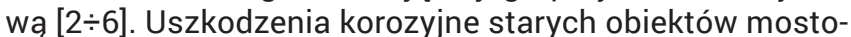
wych wymagają naprawy lub wymiany uszkodzonych elementów na nowe. Wymiana elementów w konstrukcjach nitowanych jest pracochłonna i kosztowna, a przy dużych uszkodzeniach korozyjnych racjonalna jest niekiedy wymiana całego ustroju nośnego. Obecnie przy modernizacji tych obiektów prace naprawcze wykonuje się z wykorzystaniem spawania $[6,7]$.

W artykule przedstawiono naprawę krótkiego przęsła stalowego wiaduktu kolejowego, którego skorodowane obszary naprawiono przez naspawanie elementów wzmacniających. Wykazane problemy techniczno-spawalnicze z tym związane są przyczynkiem do realizowanych prac badawczych związanych z zachowaniem i trwałością wiekowych mostów kolejowych.

\section{Charakterystyka wiaduktu}

Jednoprzęsłowy, stalowy nitowany wiadukt kolejowy jest usytuowany w km 16,365 na linii nr 149 Zabrze Makoszowy-Leszczyny (rys. 1). Ustrojem nośnym, będącym przedmiotem analizy, jest ukośne przęsło blachownicowe z pomostem otwartym i jezdnią dolną usytuowane pod torem $\mathrm{nr}$ 1. Modernizację przęsła wykonano w ramach projektu pn.: „Udrożnienie podstawowych ciągów wywozowych w ruchu towarowym na terenie Śląska, etap IV". Blachownicowe dźwigary główne przęsła o rozpiętości podporowej 9,22 $\mathrm{m}, \mathrm{w}$ rozstawie poprzecznym 3,03 m, mają środnik o przekroju $13 \times 806 \mathrm{~mm}$ i pasy o przekroju $12 \times 300 \mathrm{~mm}$. W części środkowej pasy wzmocnione są dwiema nakładkami o przekroju $12 \times 300 \mathrm{~mm}$. Połączenie pasów ze środnikiem wykonstruowano za pomocą dwu-

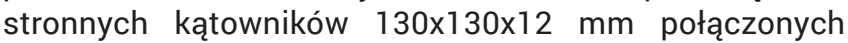
nitami $\varnothing 23 \mathrm{~mm}$. Na dźwigarach głównych, w rozstawie co $1,800 \mathrm{~m}$ (pola skrajne) i 1,855 m (pola środkowe), oparte są poprzecznice wykonane $z$ dwuteownika NP400 wraz z podłużnicami z $1320 \mathrm{w}$ rozstawie 1,70 m (rys. 2). Na podłużnicach oparte są mostownice drewniane z szynami typu 60E1. Sztywność przestrzenną konstrukcji zapewnia poziome stężenie wiatrowe typu X (z kątowników $65 \times 65 \times 7 \mathrm{~mm})$.

Dr inż. Janusz Hołowaty; dr hab. inż. Bernard Wichtowski, em. prof. ZUT - Zachodniopomorski Uniwersytet Technologiczny w Szczecinie.

Autor korespondencyjny/Corresponding author: jah@wp.pl 


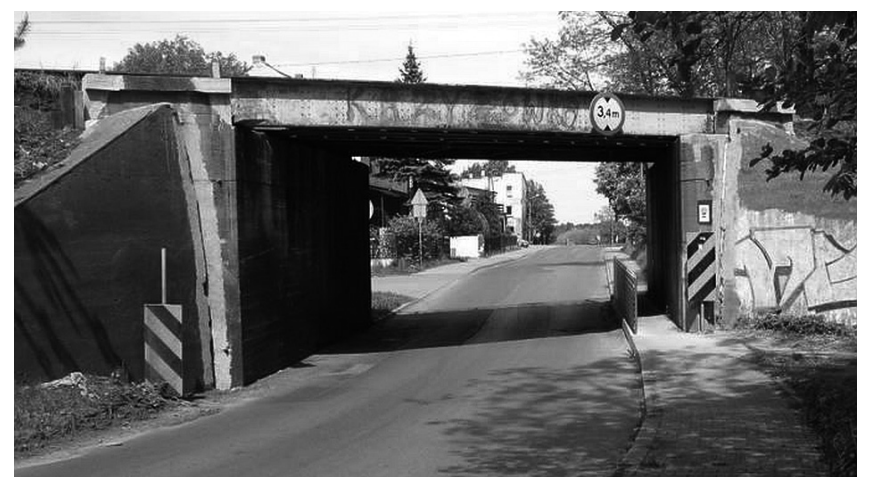

Rys. 1. Widok ogólny wiaduktu

Fig. 1. General view of the viaduct

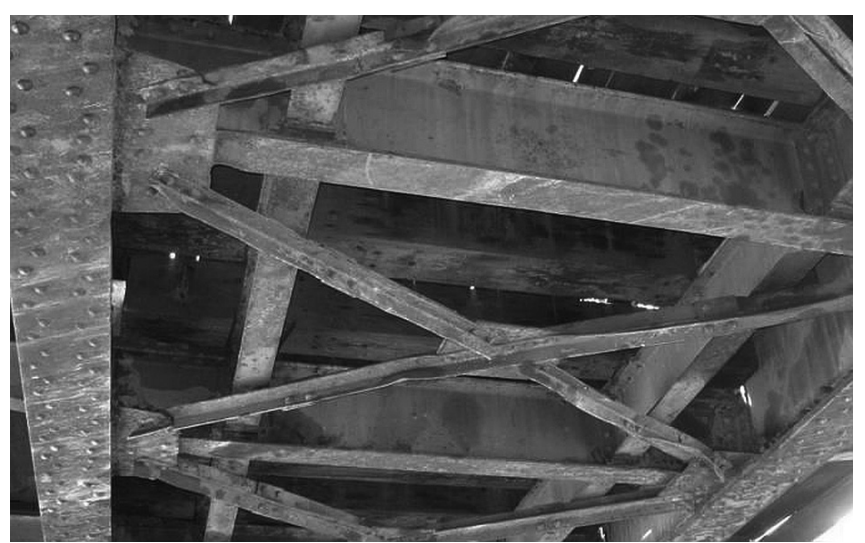

Rys. 2. Konstrukcja przęsła przed naprawą

Fig. 2. The span before refurbishment

Obiekt został oddany do użytkowania w 1907 roku. W roku 2015 przewidziano przeprowadzenie prac naprawczych przyczółków betonowych ze skrzydłami, wymianę uszkodzonych elementów stężeń wiatrowych i renowację nawierzchni torowej oraz wykonanie nowego zabezpieczenia antykorozyjnego. W odniesieniu do konstrukcji stalowej, prace naprawcze ograniczono do konstrukcji przęsła $\mathrm{w}$ torze $\mathrm{nr}$ 1. Montaż nowych mostownic przewidziano na podkładkach centrujących, przyspawanych do pasa górnego podłużnic z I320 spoinami pachwinowymi grubości $a=6 \mathrm{~mm}$. Podkładki te o długości $240 \mathrm{~mm}$ i grubości
30 mm mają zmienną wysokość od 38 do 70 mm, dostosowaną do niwelety torów.

Fakt spawania podmostownicowych podkładek centrujących zobligował wykonawcę remontu do określenia gatunku stali podłużnic i jej spawalności. Parametry te określił Instytut Spawalnictwa w Gliwicach na podstawie badań chemicznych [8]. Ustalono, że jest to stal łatwo spawalna o zawartości węgla $0,142 \%$ i równoważniku węgla $\mathrm{CEV}=0,231 \%$. Przyjęto, że jest to stal konstrukcyjna niestopowa ogólnego przeznaczenia gatunku St0S wg PN-88/H-84020 lub S185 wg PN-EN 10025-2 o granicy plastyczności $R_{\mathrm{eH}}$ nie przekraczającej $200 \mathrm{MPa}$. Z uwagi na zawartość $0,012 \%$ krzemu, mniej od wartości $0,10 \%$, stal zaliczono do stali nieuspokojonej (tabl. I).

\section{Stan techniczny konstrukcji stalowej}

Pierwotny projekt remontu przęsła $\mathrm{w}$ torze $\mathrm{nr} 1 \mathrm{w}$ odniesieniu do konstrukcji stalowej, przewidywał: wymianę uszkodzonych prętów stężenia wiatrowego w 4 polach wraz z wymianą blach węzłowych (rys. 2), przyspawanie podkładek centrujących pod mostownice i renowację pokrycia malarskiego. Po oczyszczeniu strumieniowo-ściernym stalowych elementów nośnych, rzeczywisty stan konstrukcji okazał się bardzo zły. W wielu elementach stwierdzono znaczne zniszczenie korozyjne ich przekrojów oraz występowanie perforacji. Uwaga ta dotyczy w szczególności dolnych stref środników dźwigarów głównych oraz poprzecznic skrajnych (rys. 3).

Opracowano dodatkowy projekt naprawy konstrukcji, który w niepełnym zakresie przedstawiono na rysunku 4. Wzmocnienia wykonstruowano w zależności od charakteru i stopnia skorodowania poszczególnego elementu w poniższy sposób:

a) wzmocnienie dolnej, przypasowej strefy środnika blachownic przez założenie pomiędzy poprzecznicami, na całej długości podporowej, jednostronnych nakładek o długościach 1630 mm i przekroju poprzecznym 10×200 $\mathrm{mm}$ (rys. 4a),

b) wzmocnienie środników strefy podporowej wszystkich siedmiu poprzecznic przez naspawanie jednostronnych trójkątnych nakładek o $t=8 \mathrm{~mm}$ i przekroju $270 \times 285 \mathrm{~mm}$

Tablica I. Skład chemiczny stali starych, badanych i elementów wzmacniających

Table I. Chemical composition of old, tested and strengthen elements steels

\begin{tabular}{|c|c|c|c|c|c|c|c|c|c|}
\hline \multirow{2}{*}{ Rodzaj stali } & \multicolumn{9}{|c|}{ Zawartość pierwiastka [\%] } \\
\hline & $\mathrm{C}$ & $\mathrm{Mn}$ & $\mathrm{Si}$ & $\mathrm{P}$ & S & $\mathrm{Cu}$ & $\mathrm{Cr}$ & $\mathrm{Ni}$ & $\mathrm{Al}$ \\
\hline Zgrzewna & $\begin{array}{c}0,018 \\
\div 0,300\end{array}$ & $\begin{array}{c}\text { ślady } \\
\div 0,330\end{array}$ & $\begin{array}{c}0,010 \\
\div 0,330\end{array}$ & $\begin{array}{c}0,020 \\
\div 0,460\end{array}$ & $\begin{array}{c}0,010 \\
\div 0,060\end{array}$ & - & - & - & - \\
\hline Zlewna & $\begin{array}{c}0,030 \\
\div 0,350\end{array}$ & $\begin{array}{c}0,040 \\
\div 0,750\end{array}$ & $\begin{array}{c}\text { ślady } \\
\div 0,180\end{array}$ & $\begin{array}{c}0,004 \\
\div 0,160\end{array}$ & $\begin{array}{c}0,004 \\
\div 0,115\end{array}$ & $\begin{array}{c}0,110 \\
\div 0,140\end{array}$ & $\begin{array}{c}0,007 \\
\div 0,014\end{array}$ & $\begin{array}{c}0,030 \\
\div 0,040\end{array}$ & $\begin{array}{c}0,010 \\
\div 0,020\end{array}$ \\
\hline S - belka & 0,20 & 0,48 & 0,02 & 0,019 & 0,024 & - & - & - & - \\
\hline$P-1400$ & 0,11 & 0,43 & 0,006 & 0,026 & 0,033 & - & - & - & - \\
\hline$M-1320$ & 0,08 & 0,36 & 0,01 & 0,019 & 0,038 & - & - & - & - \\
\hline M - I320 (IS) & 0,142 & 0,333 & 0,012 & 0,051 & 0,051 & 0,066 & 0,268 & 0,220 & 0,006 \\
\hline$K-L 80 \times 8$ & 0,17 & 0,36 & 0,01 & 0,026 & 0,047 & - & - & - & - \\
\hline St3M & $\max 0,20$ & $\min 0,40$ & $\begin{array}{c}0,12 \\
\div 0,30\end{array}$ & $\begin{array}{c}\max \\
0,050\end{array}$ & $\begin{array}{c}\max \\
0,050\end{array}$ & - & $\max 0,30$ & $\max 0,30$ & $\min 0,02$ \\
\hline S355J2 & $\max 0,20$ & $\max 1,60$ & $\max 0,55$ & $\begin{array}{c}\max \\
0,025\end{array}$ & $\begin{array}{c}\max \\
0,025\end{array}$ & $\max 0,55$ & - & - & - \\
\hline
\end{tabular}



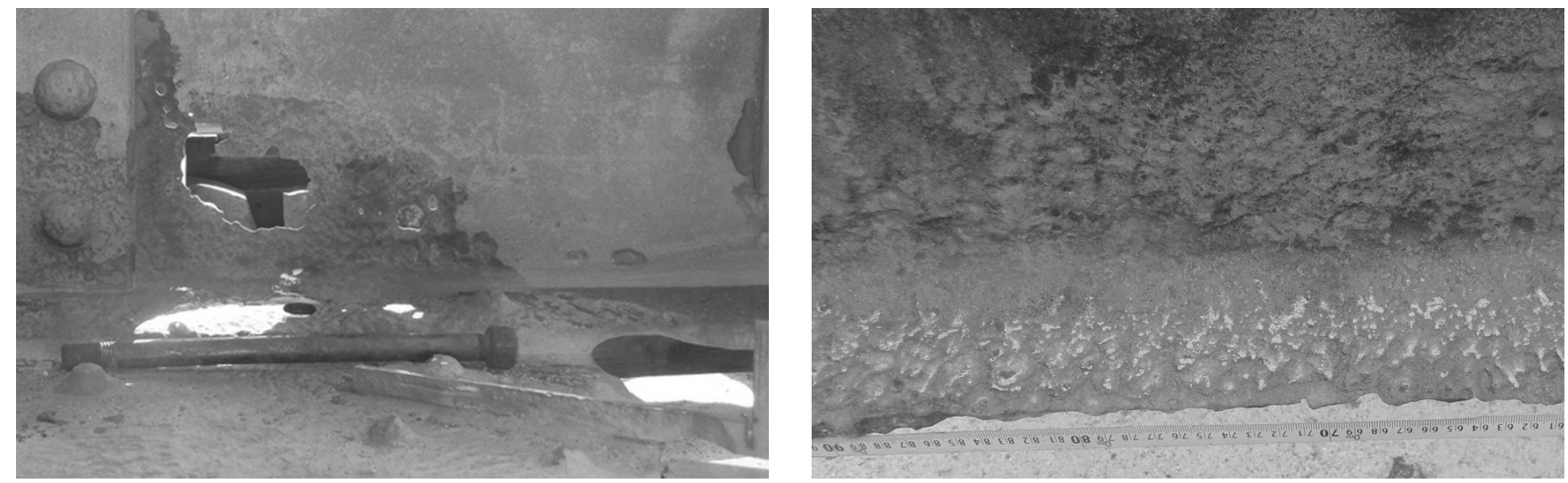

Rys. 3. Korozja strefy dolnej środnika blachownicy i pasa dolnego 1400 poprzecznicy skrajnej

Fig. 3. Corroded areas in the plate girder web and the bottom flange of the end cross beam 1400

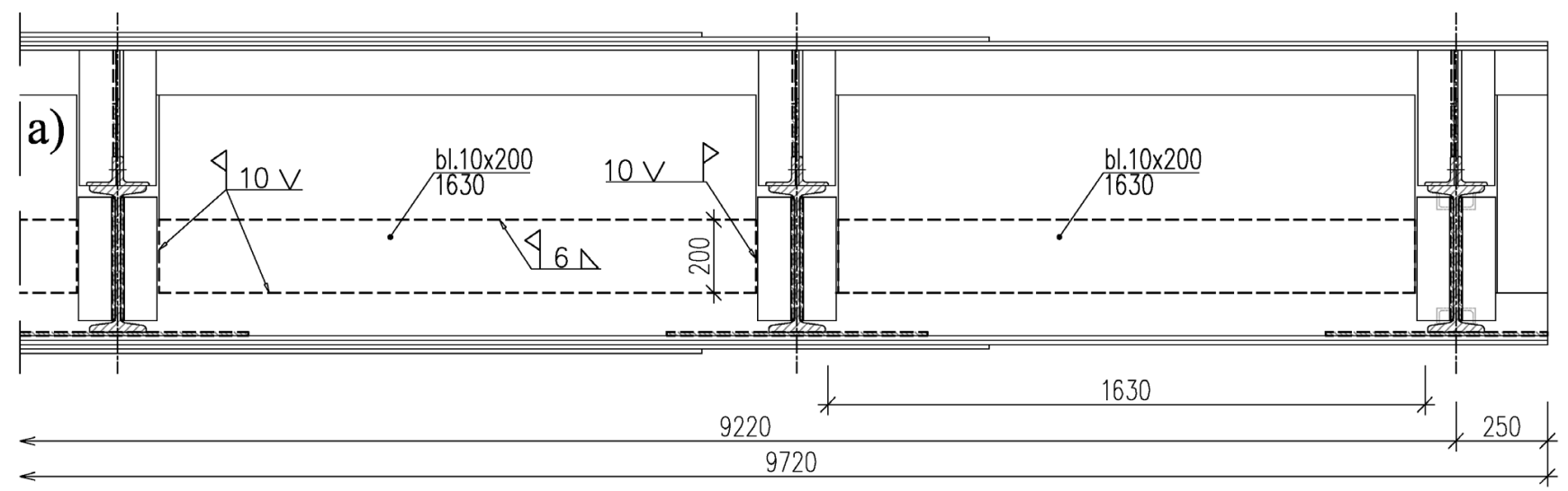

b)

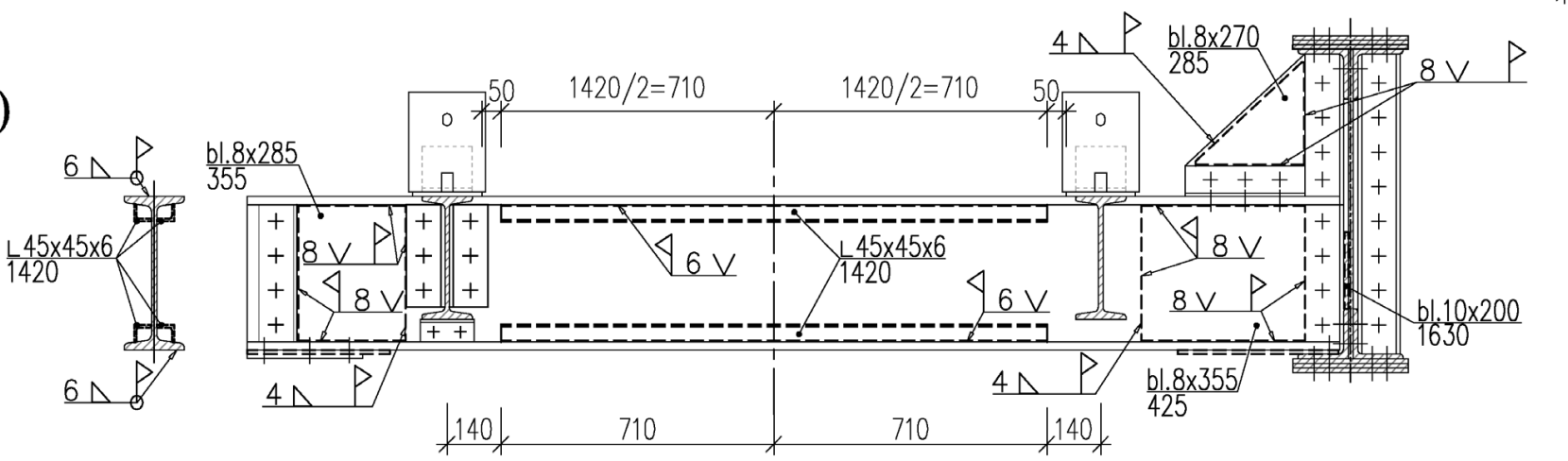

Rys. 4. Wzmocnienie: a) dźwigara blachownicowego, b) poprzecznicy skrajnej

Fig. 4. The strengthening of: a) the plate girder, b) the end cross beam

na środnik górnego żeberka podporowego oraz założenie dwustronnych nakładek o $t=8 \mathrm{~mm}$ i przekroju $355 \times 425$ $\mathrm{mm}$ na środnik poprzecznicy (rys. 4b),

c) wzmocnienie środnika wspornikowego odcinka poprzecznic skrajnych przez naspawanie dwustronnych nakładek o $t=8 \mathrm{~mm}$ i przekroju $285 \times 355 \mathrm{~mm}$ oraz na odcinku pomiędzy podłużnicami, na długości 1420 mm, wzmocnienie obu pasów tych poprzecznic dwustronnie przyspawanymi kątownikami 45×45×6 mm (rys. 4b).

Poza wyżej podanymi elementami wzmacniającymi przewidziano wymianę niektórych skorodowanych blach węzłowych oraz blach do mocowania mostownic. Wszystkie nowo projektowane elementy na rysunku 4 zaznaczono linią przerywaną.

\section{Badania chemiczne stali elementów wzmacnianych wiaduktu}

Zły stan techniczny konstrukcji przęsła wiaduktu wymusił naprawę i wzmocnienie dużej części elemen- tów nośnych. Zastosowano spawanie przy połączeniach nowych elementów wzmacniających: w środnikach dźwigarów głównych (S), w poprzecznicach z 1400 (P), podłużnicach z I320 (M) i kątownikach połączeniowych L80×80×8 mm (K). Wymagało to sprawdzenia parametrów stali tych wzmacnianych elementów i jej spawalności. Z elementów przewidzianych do wzmocnienia wycięto po dwie próbki, łącznie 8 sztuk, celem poddania ich badaniom chemicznym i wytrzymałościowym. Wyniki analizy chemicznej stali wyciętych próbek, wykonanej metodą "na mokro", przedstawiono w tabl. I. W tablicy tej podano również skład chemiczny stali środnika podłużnicy (I320), określony wcześniej przez Instytut Spawalnictwa (IS), oraz dla całościowego zobrazowania zagadnienia skład chemiczny stali z okresu budowy obiektu i stali St3M oraz S355J2 przewidzianej na elementy wzmacniające. $Z$ analizy składu chemicznego stali poszczególnych elementów nośnych obiektu (S, P, M i K) wynika, że wiadukt został zbudowany ze stali zlewnej nieuspokojonej o znacznie zróżnicowanej zawartości pierwiastków w stali badanych próbek. 


\section{Właściwości mechaniczne stali}

W celu przybliżonego oszacowania właściwości wytrzymałościowych stali poszczególnych elementów mostowych, określono ich twardość metodą Brinella (tabl. II). Uwzględniając uzyskane wartości średnie HB, wyznaczono według PN-EN ISO 6506-4:2002, przy stosunku $R_{e} / R_{m}=0,65 \div 0,80$, wartości wytrzymałości na rozciąganie $\mathrm{R}_{\mathrm{mB}}$, a po przyjęciu wartości $\alpha=R_{e B} / R_{m B} \mathrm{z}$ [2] określono $R_{e B}$. Po odrzuceniu wartości skrajnych ostatecznie dla stali wiaduktu otrzymuje się:

- wytrzymałość na rozciąganie $-R_{m B}=f_{u}=365 \mathrm{MPa}$

- granica plastyczności $-R_{e B}=f_{u}=260 \mathrm{MPa}$.

Wymiary pobranych próbek z wiaduktu uniemożliwiały wykonanie próbek okrągłych do badań statycznego rozciągania. Przeprowadzono natomiast badanie statycznego rozciągania trzech próbek z poprzecznymi złączami spawanymi o geometrii zgodnej z wymogiem PN-EN ISO 4136 (rys. 5). Próbka $S$ z blachy środnika dźwigara nośnego miała spoinę czołową o przekroju poprzecznym 9,32×12,10 mm, próbka $\mathrm{P}$ z poprzecznicy o przekroju $9,08 \times 6,91 \mathrm{~mm}$, a próbka M z podłużnicy o przekroju 9,53×7,28 mm. Próbki badano na zrywarce bez możliwości wykonania wykresu ich rozciągania. Dwie próbki zostały zerwane w materiale poza spoiną, a próbka $\mathrm{M}$ w spoinie z brakiem przetopu o szerokości ok. $3 \mathrm{~mm}$. Wyznaczone wartości materiałowe z badań przedstawiono w tablicy II.

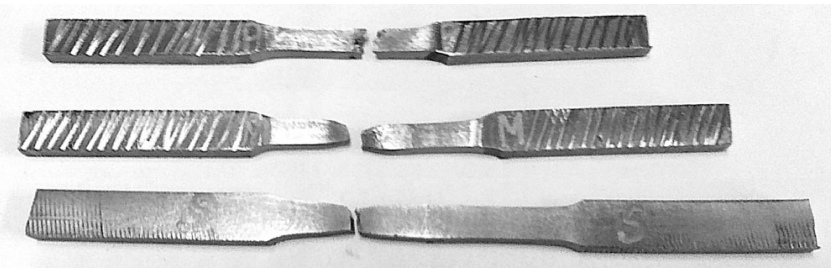

Rys. 5. Spawane złącza doczołowe po próbie rozciągania

Fig. 5. Welded butt joints after tensile test

Określone wartości średnie $R_{e}$ i $R_{m}$ są nieznacznie większe od wartości uzyskanych z badań twardości stali; wartość $R_{e}=280 \mathrm{MPa}$ jest większa o 8,9\%, a wartość $R_{m}=419 \mathrm{MPa}$ o $14,8 \%$.

Ocenę zachowania się stali z wiaduktu w wypadku ewentualnego wystąpienia warunków sprzyjających kruchemu pęknięciu spowodowanemu obecnością karbu i odkształceniami o dużej szybkości, powstałymi w wyniku udarowego działania siły, przeprowadzono na podstawie próby udarności. Badania przeprowadzono na próbkach Charpy'ego (KCV) zgodnie z wymogiem PN-EN ISO 4136. Łącznie badaniom poddano 20 próbek, po 5 dla elementu S, P, M i K, a uzyska- ne wyniki przedstawiono graficznie na rysunku 6. Uzyskano niskie wartości udarności w temperaturze ujemnej, co jest zjawiskiem naturalnym dla starych stali zlewnych. Nie wskazuje to jednak na możliwość wystąpienia kruchych pęknięć w konstrukcji wiaduktu $[2,5,6]$.

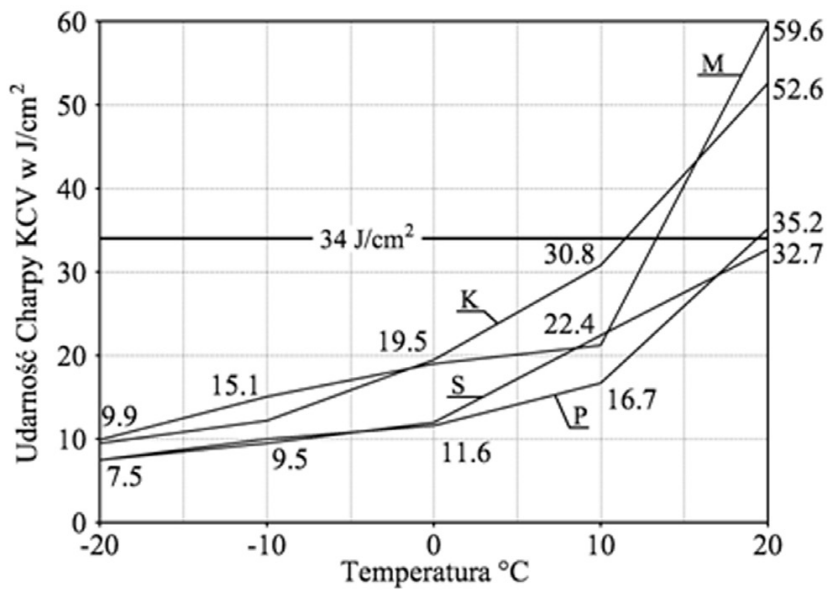

Rys. 6. Udarność badanej stali czterech elementów wiaduktu Fig. 6. Toughness of tested steel in four viaduct members

\section{Ocena spawalności stali}

Spawalność stali czterech analizowanych elementów konstrukcyjnych wiaduktu określono według wskaźników spawalności $[2,5,6]$. Obliczone wartości równoważnika węgla są w przedziale $C_{e}=0,19 \div 0,31$ (rys. 7 ). Wszystkie określone wartości wskaźników są mniejsze od wartości granicznych. Stal wiaduktu jest spawalna bez ograniczeń.

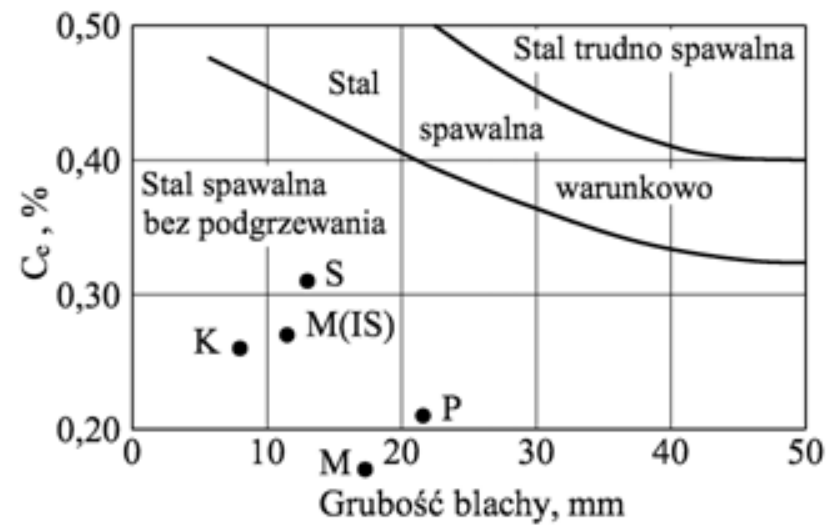

Rys. 7. Spawalność stali elementów wiaduktu w zależności od $\mathrm{C}_{\mathrm{e}}$ i grubości blachy

Fig. 7. Weldability of steel for viaduct members according to $C_{e}$ and plate thickness

Tablica II. Właściwości mechaniczne stali

Table II. Mechanical properties of steel

\begin{tabular}{|l|c|c|c|c|c|c|c|}
\hline \multirow{2}{*}{ Próbka } & \multicolumn{4}{|c|}{ Badania twardości } & \multicolumn{4}{c|}{ Rozciąganie złączy } \\
\cline { 2 - 9 } & HB10 & $R_{m B}[\mathrm{MPa}]$ & $\mathrm{a}[2]$ & $R_{e B}[\mathrm{MPa}]$ & $\mathrm{A}\left[\mathrm{mm}^{2}\right]$ & $R_{e}[\mathrm{MPa}]$ & $R_{m}[\mathrm{MPa}]$ \\
\hline S - belka & 111 & 375 & 0,64 & 240 & 113,0 & 283 & 420 \\
\hline P - I400 & 105 & 355 & 0,76 & 270 & 62,8 & 270 & 414 \\
\hline M - I300 & 102 & 345 & 0,78 & 269 & 63,4 & 288 & 425 \\
\hline K - L80'8 & 115 & 386 & 0,65 & 251 & - & - & - \\
\hline Średnia & 108 & 365 & 0,71 & 257 & - & 280 & 419 \\
\hline
\end{tabular}




\section{Uwagi wykonawczo-spawalnicze}

Remont wiaduktu rozpoczęto bez dokładnego rozeznania stanu technicznego konstrukcji. Pierwotnie przewidywano spawanie jedynie podkładek centrujących pod mostownice do pasów górnych podłużnic. Rzeczywisty stan konstrukcji, po jej oczyszczeniu strumieniowo-ściernym, okazał się bardzo zły. Wykonany dodatkowy projekt naprawy zalecił wzmocnienie uszkodzonych elementów konstrukcji nośnej poprzez dospawanie elementów wzmacniających. Wymagało to uzupełniającego oszacowania właściwości materiałowych i spawalności elementów wzmacnianych. Wyniki z tych badań przedstawiono w niniejszym artykule.

$\mathrm{Na}$ elementy wzmacniające przyjęto stal S355J2 i przewidziano spawanie metodą 135: elektrodą metalową w osłonie dwutlenku węgla $\mathrm{CO}_{2}$; metodą MAG. Projekt technologiczny spawania opracowali autorzy artykułu. Z uwagi na pojedyncze elementy wzmacniające nie opracowano kart technologicznych spawania a jedynie karty instrukcyjne spoin.

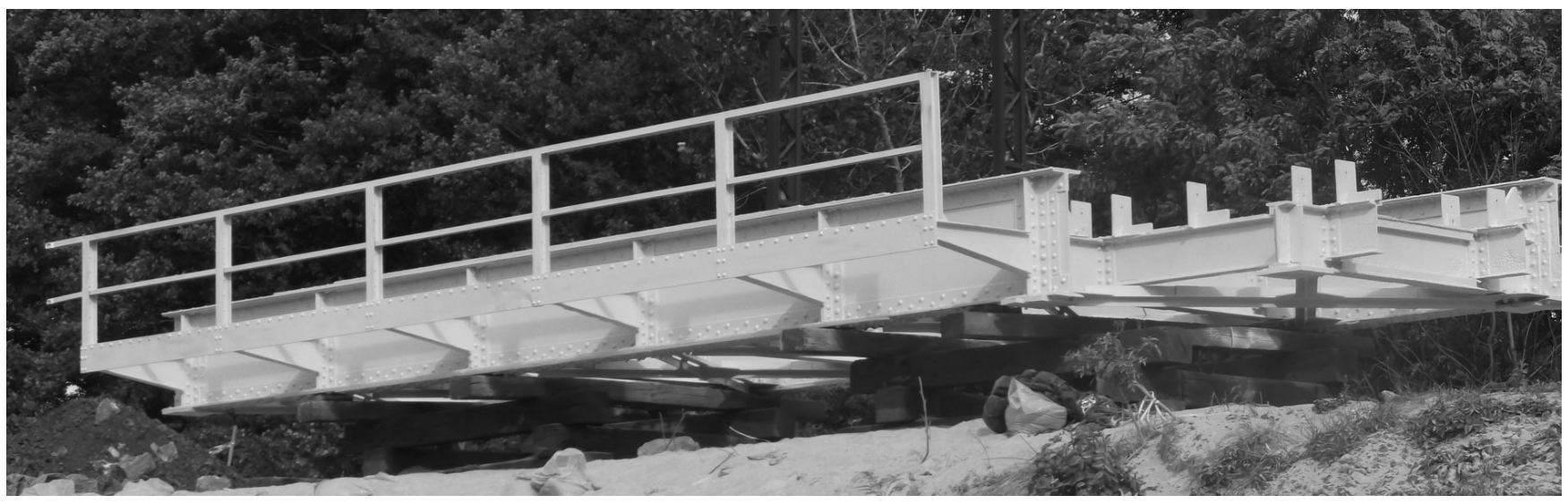

Rys. 8. Ogólny widok ukośnego przęsła wiaduktu w końcowej fazie naprawy i wzmocnienia

Fig. 8. The strengthening of: a) the plate girder, b) the end cross beam

\section{Podsumowanie}

Przedstawiona restytucja konstrukcji przęsła wiaduktu jest przykładem pomyślnego zakończenia modernizacji, do której przystąpiono bez pełnej oceny zakresu występujących uszkodzeń korozyjnych. Stwierdzony rozległy zakres uszkodzeń korozyjnych kwalifikował konstrukcję przęsła raczej do wymiany i wybudowania nowej konstrukcji. Ze względów ekonomiczno-prawnych zdecydowano się wykonać naprawę i wzmocnienie, przez przyspawanie elementów wzmacniających. Remont wykonano „bezproblemowo”, zgodnie z omówionym zakresem robót (rys. 8).

Na uwagę zasługuje również fakt przyjmowania asekuracyjnych właściwości mechanicznych stali starych konstrukcji $[2,5,6,8]$. Właściwości te dla stali wiaduktu, IS [8] określił jedynie z analizy składu chemicznego stali. Błędnie przyjęto najniższe właściwości obecnie produkowanej stali S185 o $R_{e H}=185 \mathrm{MPa}$. PN-EN 1993-1-1 nie przewiduje takiej stali na żadne konstrukcje budowlane, a tym bardziej mostowe. Dla stali tej norma hutnicza nie określa wartości pracy łamania oraz składu chemicznego. Należało przyjąć stal S235 o $R_{e}=235 \mathrm{MPa}$, tj. stal o najniższych parametrach, którą można stosować w konstrukcjach mostowych. Słuszność takiego zalecenia potwierdziły badania stali podłużnicy wiaduktu, według których $R_{e}=270 \mathrm{MPa}$. Międzynarodowy Związek Kolejowy UIC już w roku 1986 [9] zalecił, bez przeprowadzania badań materiałowych, możliwość przyjmowania dla stali zlewnej wartość granicy plastyczności $R_{e}=220 \mathrm{MPa}$.

\section{Literatura}

[1] J. Hołowaty, B. Wichtowski: O stanie technicznym najstarszego w Polsce wiaduktu drogowego ze stali zlewnej, Inżynieria i Budownictwo, nr 7-8, s. 404-407, 2013

[2] B. Wichtowski, J. Hołowaty: Analiza właściwości materiałowych i spawalności stali zlewnej mostów kolejowych, Inżynieria i Budownictwo, nr 5, s. $247-251,2013$

[3] B. Wichtowski: Wytrzymałość zmęczeniowa spawanych złączy doczołowych w stalowych mostach kolejowych, Prace Naukowe Politechniki Szczecińskiej, nr 572, KTK 1, Wydawnictwo Uczelniane PS, Szczecin 2002.

[4] B. Wichtowski, J. Hołowaty: Ocena właściwości stali mostów na modernizowanych regionalnych liniach kolejowych woj. zachodniopomorskiego Mosty, nr 2, s. 40-44, 2012.
[5] J. Hołowaty, B. Wichtowski: Problemy spawalnicze przy modernizacji starych mostów kolejowych, Przegląd Spawalnictwa, Vol. 87, $\mathrm{nr} 5$, s. 45-51, 2015.

[6] J. Hołowaty, B. Wichtowski: Właściwości stali mostu kolejowego wybudowanego w 1887 roku, Roads nad Bridges - Drogi i Mosty, nr 4, s. $271-283,2015$.

[7] D. T. Ricker: Field Welding to Existing Steel Structures, Engineering Journal, American Institute of Steel Construction, 1988.

[8] Ekspertyza Nr ZT/392/15 p.t. „Ustalenie gatunku stali blachownicy wiaduktu i ocena jej spawalności" Instytut Spawalnictwa, Gliwice 2015.

[9] B. Wichtowski: Nośność stalowych mostów kolejowych z drugiej połowy XIX wieku - uwagi dyskusyjne, Roads and Bridges - Drogi i Mosty, nr 3, s. 261-269, 2014. 